\title{
Extensive frontal grey matter volume reduction related to a possible sequelae of encephalitis
}

\author{
Alper Evrensel, ${ }^{1}$ Mehmet Emin Ceylan, ${ }^{1}$ Celal Şalçini, ${ }^{2}$ Barış Önen Ünsalver ${ }^{1}$
}

${ }^{1}$ Department of Psychiatry, Uskudar University, İstanbul, Turkey

${ }^{2}$ Department of Neurology, Uskudar University, İstanbul, Turkey

\section{Correspondence to} Dr Alper Evrensel, alperevrensel@gmail.com

Accepted 23 August 2015

\section{DESCRIPTION}

A 39-year-old man was brought to the psychiatry clinic by his relatives. According to them, the man's mental and motor development was normal until the age of 2 years, at which time he had a febrile illness with convulsions and was unconscious for 1 week. He had no rush, or other systemic signs. As he was living in a remote village, he could not be taken to a hospital, and so did not receive treatment or diagnosis. After the illness, he could not walk until he was 5 years old He could not speak, and only made meaningless sounds. At presentation, he was wandering around the examination room in a disinhibited way. His self-care was lacking. His hands and fingernails were dirty. There were selfdestructive scars on the back of his hands (figure 1).

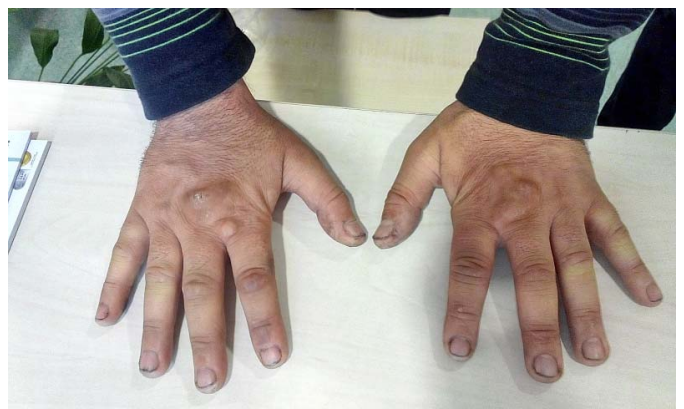

Figure 1 The patient's hands.
His relatives said the patient was overactive and needed to be under constant surveillance to keep him from hurting himself or getting lost. Neurological examination revealed frontal signs, mild global hyper-reflexia without clonus, and bilateral grasp and palmomental reflex. Brain MRI and quantitative EEG (QEEG) were performed. Brain MRI revealed extensive frontal and mild right parietal gliosis and encephalomalacia (figure 2).

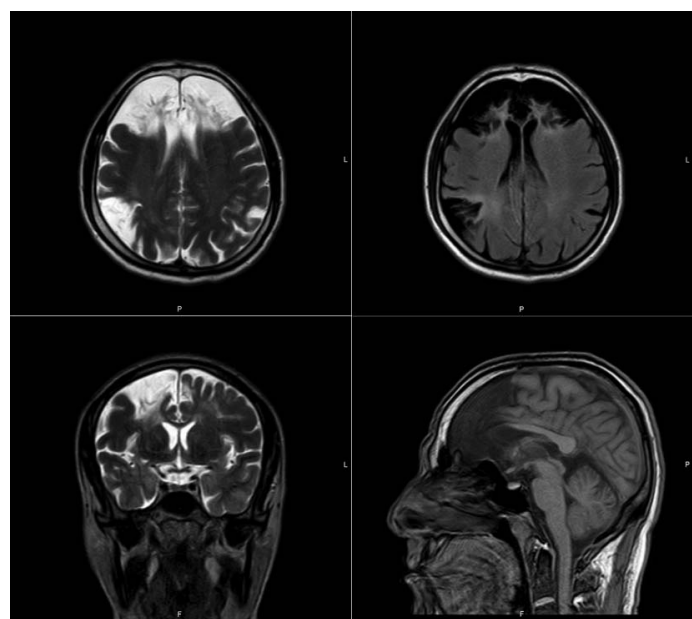

Figure 2 MRI of the brain showing extensive frontal and mild right parietal gliosis and encephalomalacia.

\section{Z Scored FFT Summary Information}

Delta

Absolute Power

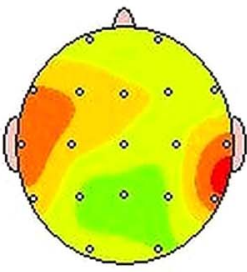

Relative Power
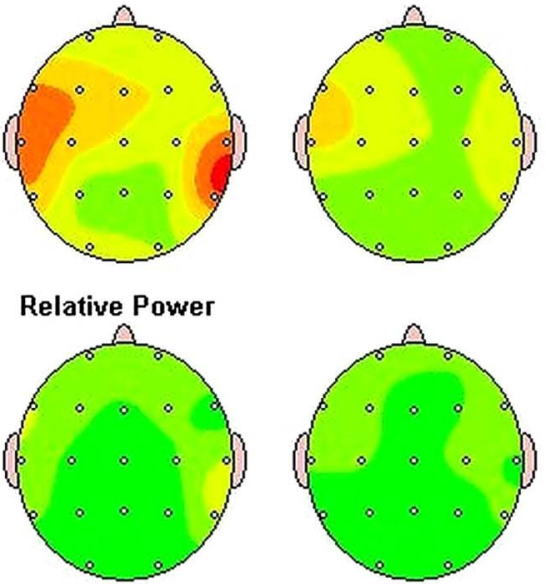

Alpha
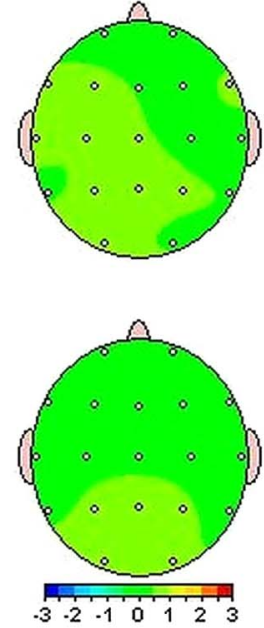

Beta
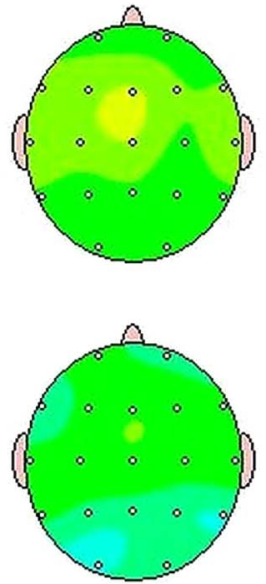

High Beta
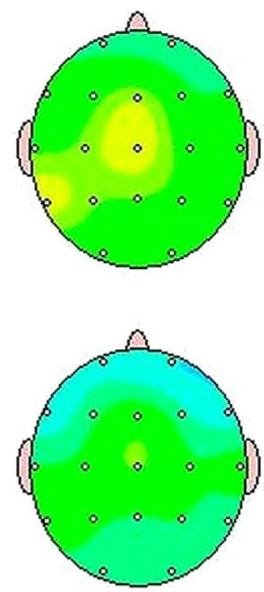
Ceylan ME, Şalçini C, et online: [please include Day Month Year] doi:10.1136/ bcr-2015-212064

Figure 3 QEEG (quantitative EEG) of the brain showing increased frontotemporal $\theta$ and $\delta$ frequency. 
QEEG revealed increased absolute $\delta$ and $\theta$ power in temporal and frontal areas (figure 3). The patient scored 34 on the Frontal Behaviour Inventory (FBI). His IQ score could not be identified as he was not cooperative. He was considered mentally retarded at the idiot level. We concluded that he had probably had untreated encephalitis when he was 2 years old, damaging the frontal region. His treatment was started with carbamazepine $800 \mathrm{mg} /$ day and risperidone $3 \mathrm{mg} /$ day. His disorganised behaviour significantly improved.

\section{Learning points}

Encephalitis sequelae can cause mental retardation.

- Frontal necrosis leads to disinhibition.

- Low doses of antipsychotics and antiepileptic drugs are useful for symptomatic treatment.
Intracranial infections in childhood may lead to consciousness disorders, behavioural changes and focal neurological symptoms. ${ }^{1}$ Encephalomalacia and gliosis may follow abscess. ${ }^{2}$ In our case, information about the acute period was not available, hence we assumed the patient had had encephalitis. Postinfectious necrosis, mainly in the frontal lobe, may have occurred.

Contributors $A E$ was involved in the patient's management and follow-up. $A E$, MEC and CS were involved in the diagnosis; AE was involved in the literature review; MEC supervised and critically reviewed the intellectual content of the manuscript. AE drafted the manuscript; CSS and BÖÜ revised the manuscript.

Competing interests None declared.

Patient consent Obtained.

Provenance and peer review Not commissioned; externally peer reviewed.

\section{REFERENCES}

1 Saini J, Gupta RK, Jain KK. Intracranial infections: key neuroimaging findings. Semin Roentgenol 2014;49:86-98.

2 Acosta JH, Rantes $\mathrm{Cl}$, Arbelaez A. et al. Noncongenital central nervous system infections in children: radiology review. Top Magn Reson Imaging 2014;23:153-64.

Copyright 2015 BMJ Publishing Group. All rights reserved. For permission to reuse any of this content visit http://group.bmj.com/group/rights-licensing/permissions.

BMJ Case Report Fellows may re-use this article for personal use and teaching without any further permission.

Become a Fellow of BMJ Case Reports today and you can:

- Submit as many cases as you like

- Enjoy fast sympathetic peer review and rapid publication of accepted articles

- Access all the published articles

- Re-use any of the published material for personal use and teaching without further permission

For information on Institutional Fellowships contact consortiasales@bmjgroup.com

Visit casereports.bmj.com for more articles like this and to become a Fellow 